\title{
Genetic Diversity Analysis of Indian Salmon, Eleutheronema tetradactylum from South Asian Countries Based on Mitochondrial COI Gene Sequences
}

\author{
Ramakrishnan THIRUMARAISELVI, Muthusamy THANGARAJ* \\ Centrefor Advanced Study in Marine Biology, Faculty of Marine Sciences, Annamalai University, Parangipettai, Tamil Nadu 608 502, \\ India; hirumaraiselvi-rtselvi.biotech@gmail.com; coralholder@yahoo.com (*correspondingauthor)
}

\begin{abstract}
Eleutheronema tetradactylum is an important commercial fish species exposed to intense exploitation both in Southeast Asian countries and Northern parts of Australia. Research on the population structure of E. tetradactylum in these coastal waters is substantial in order to ensure sustainable use and appropriate resource management. In this study, genetic variation, diversity and population structure of $E$. tetradactylum among four FAO fishing areas, along South Asian countries, were evaluated using cytochrome c oxidase subunit I (COI) gene. Totally 30 sequences of COI gene were collected from four FAO fishing areas. Among these 30 individuals, 18 distinct haplotypes were defined. High levels of haplotype diversity $(h d=0.952 \pm 0.096)$ and nucleotide diversity $(\pi=0.01536 \pm 0.00312)$ were observed in the population within the Bay of Bengal. No haplotype and nucleotide diversity were observed in South China Sea population. Hierarchical analysis of molecular variance (AMOVA) indicated that whereas $0.81 \%$ of the genetic variation occurred within the populations, $7.09 \%$ occurred among populations. Significant genealogical branches were recognized in North Australian populations (one clade), South China Sea populations (one clade), Arabian Sea and Bay of Bengal populations (one clade on the neighbor-joining tree). These results suggested that E. tetradactylum populations in FAO fishing areas 51, 57 and 61 have developed different genetic structures. Tests of neutral evolution and mismatch distribution suggest that a population growth of E. tetradactylum may take place in these fishing areas.
\end{abstract}

Keywords: COI, Eleutheronema tetradactylum, genetic diversity, genetic variation, population structure

\section{Introduction}

The Indian salmon, E. tetradactylum is a pelagic-neritic fish species that belongs to the Polynemidae family, which is mainly distributed in the Indo-West-Pacific region: from Persian Gulf to Papua New Guinea, Northern Australia and East Asia (Japan, China, Vietnam) (Yamada et al., 1995). E. tetradactylum prefers shallow turbid water, soft substrates and is found in a variety of near-shore habitats (Horne et al., 2011). However, fisheries of $E$. tetradactylum have drastically decreased in recent years due to overexploitation and water pollution (Motomura et al., 2002; Newman et al., 2011). E. tetradactylum is a protandrous hermaphrodite that becomes female after 2 years, with a maximum lifespan of approximately 7 years reaching more than 1 meter length (Horne et al., 2011). The location of spawning is unknown in this species but both eggs and larvae are pelagic, suggesting a high dispersal potential (Horne et al., 2011). There are no data on pelagic larval duration for this species in the wild, where the larvae reach a maximum length of $30 \mathrm{~mm}$ (Motomura, 2004). This species is also a commercially important fish that is harvested on a large scale between Kuwait and
Northern Australia (Motomura, 2004), but more knowledge is needed about the stock structure for proper management of this fishery (Welch et al., 2002). Earlier studies show that the dispersal of this species is sufficiently low to make inferences about the ecological connectivity levels, which are the most relevant concerning management (Jones et al., 2009; Horne et al., 2011). A number of studies have been carried out on Polynemidae fish stock structures using molecular markers. Zischke et al. (2009) determined the stock structure of blue thread fin E. tetradactylum along the East Queensland Coast using parasites and conventional tagging. Moore et al. (2011) investigated the stock structure of E. tetradactylum across Tropical Northern Australia using stable isotopes in sagittal otolith carbonates.

Molecular markers can be used to effectively estimate genetic variation and population structure in different populations, thereby providing a basis for better management of whole populations and thence sustainable fisheries (Liu et al., 2009; Yue et al., 2009). The COI gene is well characterized and is frequently used for genetic studies in invertebrates and vertebrates (Ward et al., 2005; Spies et al., 2006). In addition, variations in the COI gene 
418

sequence have been employed to resolve population analysis in fish species such as Pampus argenteus, Coilia ectenes, Nibea albiflora and E. rhadinum (Peng et al., 2009; Ma et al., 2010; Xu et al., 2012; Sun et al., 2013). In the present study, COI gene sequence was used to assess genetic divergence and genetic connectivity among six E. tetradactylum populations along the Seas of the Indian Ocean, South China Sea and North Australian Seas.

\section{Materials and Methods}

\section{Sample collection}

Five E. tetradactylum individuals were collected from Parangipettai, Tamil Nadu and from the Bay of Bengal. All of the individuals were identified based on morphological characteristics according to the description of Motomura $e t$ al. (2002). After collection muscle samples were preserved in 95\% ethanol for DNA extraction. To support the hereby studied COI data, another two sequences for the Bay of Bengal, another three for Arabian Sea and another five (one for each) for South China Sea, North West Australia, North Australia and North East Australian waters were retrieved from NCBI GenBank. Map of FAO fishing zones and detailed information concerning the sequences is shown in Fig. 1 and Table 1.

\section{$D N A$ isolation, amplification and sequencing}

From the stored tissues, DNA was isolated by standard Proteinase-K/Phenol- Chloroform- Ethanol method (Sambrook et al., 1989) and the concentration of isolated DNA was estimated using a UV spectrophotometer. The DNA was diluted in TAE buffer to a final concentration of $100 \mathrm{ng} / \mu \mathrm{l}$. The COI gene was amplified in a $50 \mu \mathrm{l}$ volume PCR mix with $5 \mu$ l of $10 \mathrm{X}$ Taq polymerase $\mathrm{MgCl}_{2}(25 \mathrm{mM})$

Table 1. COI sequence of E. tetradactylum used in this study

\begin{tabular}{lcc}
\hline Population & Accession Number & Reference \\
\hline Arabian Sea & EF609512-13,FJ347964 & Lakra et al.,2011 \\
Bay of Bengal & FJ384688, FJ265858 & Unpublished \\
South ChinaSea & KC576977,KC576979, KJ468462-64 & Present study \\
North East Australia & EU59510408 & Unpublished \\
North West Australia & JF513700-04 & Horne et al.,2011 \\
North Australia & JF513880-84 & Horne et al.,2011 \\
\hline
\end{tabular}

buffer, $1 \mu l$ of each dNTP $(0.05 \mathrm{mM}), 1 \mu \mathrm{l}$ of each primer $(0.01 \mathrm{mM}), 0.6 \mathrm{U}$ of Taq polymerase, $2 \mu \mathrm{l}$ of genomic DNA and $36 \mu$ lof double distilled water. The universal primer, $F i s h F 1$ 5'TCAACCAACCACAAAGACATTGGCAC3' and FishRI - 5'TAGACTTCTGGGTGGCCAAAGAATCA3' (Ward et al., 2005) was used for the amplification of the CO1 gene. The thermal regime consisted in an initial step of 2 min at $95^{\circ} \mathrm{C}$ followed by 35 cycles of $40 \mathrm{sec}$ at $94^{\circ} \mathrm{C}, 40 \mathrm{sec}$ at $54^{\circ} \mathrm{C}$ and $60 \mathrm{sec}$ at $72^{\circ} \mathrm{C}$ followed by final extension of 10 min at $72{ }^{\circ} \mathrm{C}$. The PCR products were checked using $1.5 \%$ agarose gel and the most representative bands were selected for sequencing. The cleaned up PCR product was sequenced by a commercial sequencing facility (Eurofin Genomics, Bangalore, India).

\section{Sequence analysis}

The COI gene partial sequences of five individuals were edited using MEGA 4.0 (Tamura et al., 2007) and aligned with Clustal W 1.6, included in the same software. The haplotype definitions have been submitted to the NCBI GenBank. The genetic diversity indices such as nucleotide diversity $(\pi)$ (Lynch and Crease, 1990) and haplotype diversity (bd) (Nei, 1987), were calculated in Dnasp 4.0 (Rozas et al., 2003). Genetic relationships among individuals were constructed based on the neighbor-joining $(\mathrm{NJ})$ method (Saitou and Nei, 1987). In order to illustrate the phylogenetic and geographical relationships of the haplotype sequences, a haplotype network was created with the median-joining in Network 4.1 (Röhl and Mihn, 2003). A hierarchical analysis of molecular variance (AMOVA) was performed to reveal the geographical structure of genetic variation using ARLEQUIN version 3.1 (Excoffier et al., 2008). The significance of the fixation index was tested by 1000 permutations of the data set. The population genetic structure within the six fishing zones were revealed by pairwise $F$ statistics in ARLEQUIN version 3.1 (Excoffier $e t$ al., 2008). Tajima's $D$ (Tajima, 1989), Fu and Li's $D$ and Fu's $F_{\mathrm{S}}(\mathrm{Fu}, 1997)$ was calculated to verify the null hypothesis of selective neutrality in relation to mtDNA sequences, which would be expected with population expansion. Mismatch distributions (Harpending et al., 1993) were constructed in Dnasp 4.0 (Rozas et al., 2003). The shapes of the mismatch distributions were used to deduce whether a population has undergone a sudden population expansion (Rogers, 1995).

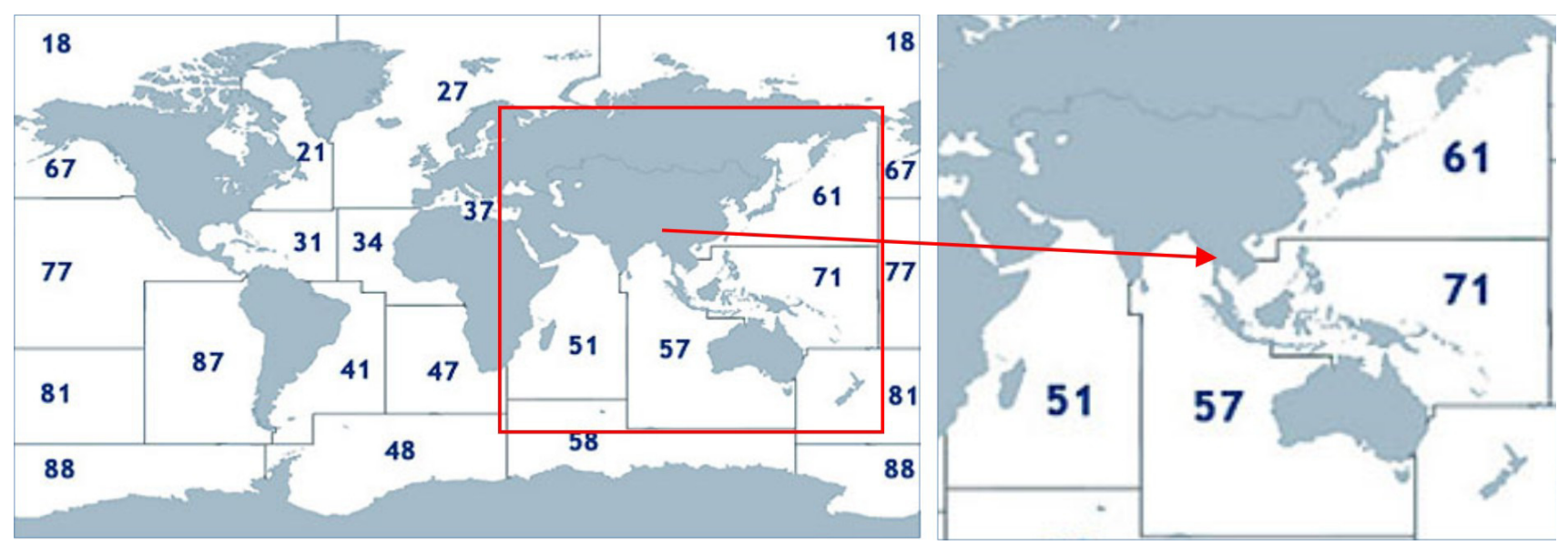

Fig. 1. Map showing the studied FAO fishing zones 
Significance was assessed on the parameters with permutation tests under the null hypothesis that a sudden population expansion cannot be rejected.

\section{Results and Discussion}

\section{Genetic variation}

The 5' partial fragment of 614 bp of E. tetradactylum COI gene was amplified and sequenced from all the five collected individuals of the present study and 25 Genbank sequences were analyzed. The average contents of $\mathrm{A}, \mathrm{T}, \mathrm{G}$, and $C$ were $22.6 \%, 29.1 \%, 19.2 \%$ and $29.1 \%$. Among the 30 sequences 18 haplotypes were defined and no insertions or deletions were found. The number of haplotypes (b), haplotype diversity $(h d)$ and nucleotide diversity $(\pi)$ within each population are presented in Table 2. The South China population had the lowest number (one) of haplotypes and the lowest genetic diversity $(h d=0.000 \pm 0.000, \pi=0.00000$ $\pm 0.00000)$, while the Bay of Bengal population was the highest in all concerns $(h=6, h d=0.952 \pm 0.096, \pi=$ $0.01536 \pm 0.00312$ ).

\section{Population genetic structure and genetic distance}

A neighbor-joining $(\mathrm{NJ})$ tree for the six E. tetradactylum populations comprising 30 individuals was constructed based on the Kimura-2-parameter (K2P) distance model (Fig. 2).

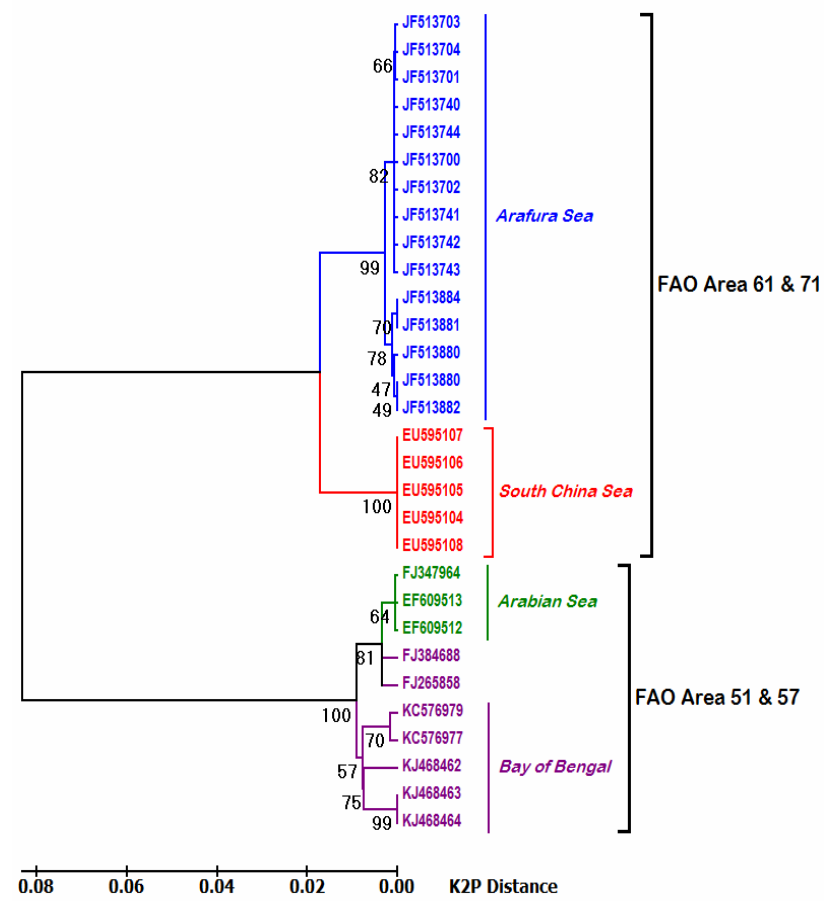

Fig. 2. NJ tree according to haplotypes from four FAO fishing area of E. tetradactylum based on COI gene sequences
The NJ tree was deep and there were significant genealogical branches corresponding to populations in FAO fishing areas (51, 57 and 61). Furthermore, to illustrate the phylogenetic and geographical relationships between the identified sequences, haplotype networks were constructed using the median-joining method. Only one haplotype was shared by Northern and North East Australian populations that might be the ancestral haplotype for Australian populations. No other haplotypes were shared by any other populations (Fig. 3). The K2P genetic distance and F $\mathrm{F}_{S T}$ value between the six populations are given in Table 3. All the populations exhibited significant genetic differences except the ones between the Arabian Sea and Bay of Bengal as well as North Australia and North West Australian populations. The analysis of molecular variance was performed based on haplotype frequencies to test for large-scale patterns of genetic structure (Table 4). Results show that only $0.81 \%$ of the genetic variation occurred within the populations, whereas $7.09 \%$ occurred among populations.

\section{Tests of neutrality and population expansion estimation}

Tests for neutral evolution were performed to ascertain the evidence of purifying or balancing selections. The Fu's $\mathrm{F}$ tests resulted in negative values almost for all of the populations despite the fact that the results were not statistically significant (Table 5). This result suggests that $E$. tetradactylum populations likely experienced a population expansion. The mismatch distribution pattern of $E$. tetradactylum among the populations is shown in Fig. 4.

In the present study, 614 bp segment of the COI gene were used to assess the genetic diversity of E. tetradactylum populations in the FAO fishing areas 51, 57, 61 and 71, including the Arabian Sea, Bay of Bengal, South China Sea and North Australian Seas. Eighteen haplotypes were defined in 30 sequences. The genetic diversity in E. tetradactylum is comparable with $E$. rhadinum populations where the mean haplotypic $(h)$ and nucleotide diversities $(\pi)$ were $0.759 \pm$ 0.035 and $0.00198 \pm 0.00326$ by COI data (Sun et al., 2013). It is important to mention that in Austlalian E. tetradactylum populations the haplotype $(b)$ and nucleotide diversity $(\pi)$ range from 0.00 to 0.83 and from 0.0000 to 0.0024 respectively as per $C y t b$ data (Horne et al., 2011). In addition a remarkable reduction was observed in genetic diversity of the Zhoushan population $(h=0.595 \pm 0.109, \pi=0.001 \pm$ $0.00155)$ compared to the Qidong $(h=0.782 \pm 0.058, \pi=$ $0.00212 \pm 0.0035)$ and Zhuhai populations $(h=0.780 \pm$ $0.059, \pi=0.00222 \pm 0.00282)$. Genetic variation within populations can be reduced through genetic drift or bottleneck in the particular population (Yue et al., 2009; Habib et al., 2011). An earlier study (Chang et al., 2012) reported that, overfishing and concomitant habitat loss in this

Table 2. Genetic diversity of E. tetradactylum populations based on COI sequence

\begin{tabular}{lccr}
\hline Population & $\begin{array}{c}\text { Haplotype } \\
\text { number }(h)\end{array}$ & Haplotype diversity $(h d)$ & Nucleotide diversity $(\pi)$ \\
\hline Arabian Sea & 2 & $0.667 \pm 0.314$ & $0.00109 \pm 0.00051$ \\
Bay of Bengal & 6 & $0.952 \pm 0.096$ & $0.01536 \pm 0.00312$ \\
South China Sea & 1 & $0.000 \pm 0.000$ & $0.00000 \pm 0.00000$ \\
North East Australia & 3 & $0.800 \pm 0.164$ & $0.00163 \pm 0.00045$ \\
North West Australia & 3 & $0.800 \pm 0.164$ & $0.00163 \pm 0.00045$ \\
North Australia & 3 & $0.700 \pm 0.218$ & $0.00261 \pm 0.00115$ \\
\hline
\end{tabular}


420

area have had a deleterious effect on population level decrease and genetic diversity, and it might be responsible for the lower genetic variation in the Zhoushan population in South China Sea. The high level of haplotypic diversity and low $\pi$ value in E. tetradactylum populations in Bay of Bengal and Australian populations suggest that this fish could have experienced a population expansion after a period of low effective population size (Grant and Bowen, 1998). This type of genetic structure has been observed in threadfin fish, $E$. rhadinum (Sun et al., 2013), long-tailed hake, Macruronus magellanicus (Machado-Schiaffino and Garcia-Vazquez, 2011)

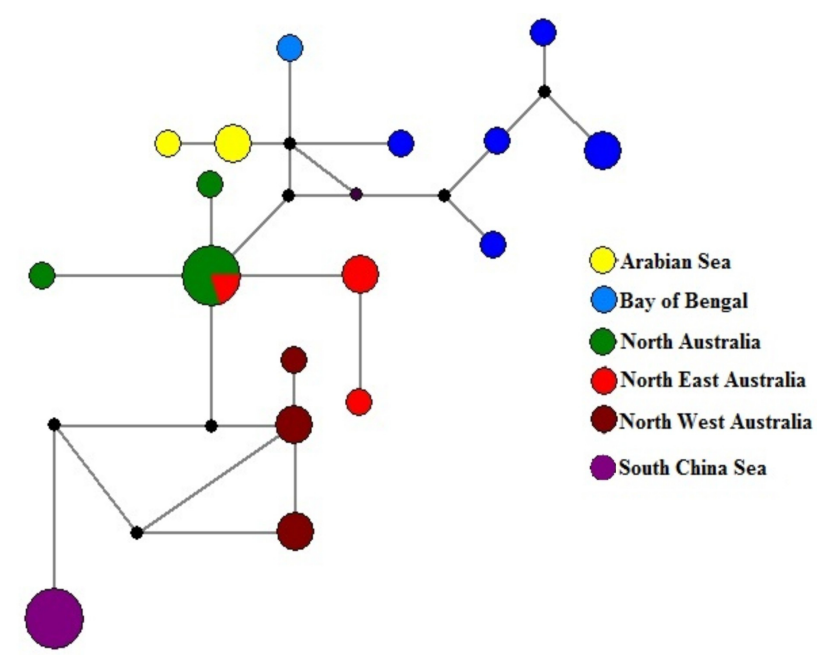

Fig. 3. Median-joining network for the COI haplotypes in $E$. tetradactylum populations. Each circle represents a unique haplotype, with the area being proportional to the frequency of the haplotypes and fat greenling, Hexagrammos otakii (Habib et al., 2011). Tajima's $D$ and Fu's $F_{S}$ analysis were also performed to check neutral evolution and mismatch distribution to explain the dimorphic history of E. tetradactylum. Negative Tajima's $D$ and Fu's $F$ s test values, although not significant, indicate a recent population expansion. The unimodal mismatched nucleotide frequency distribution supports the occurrence of a recent
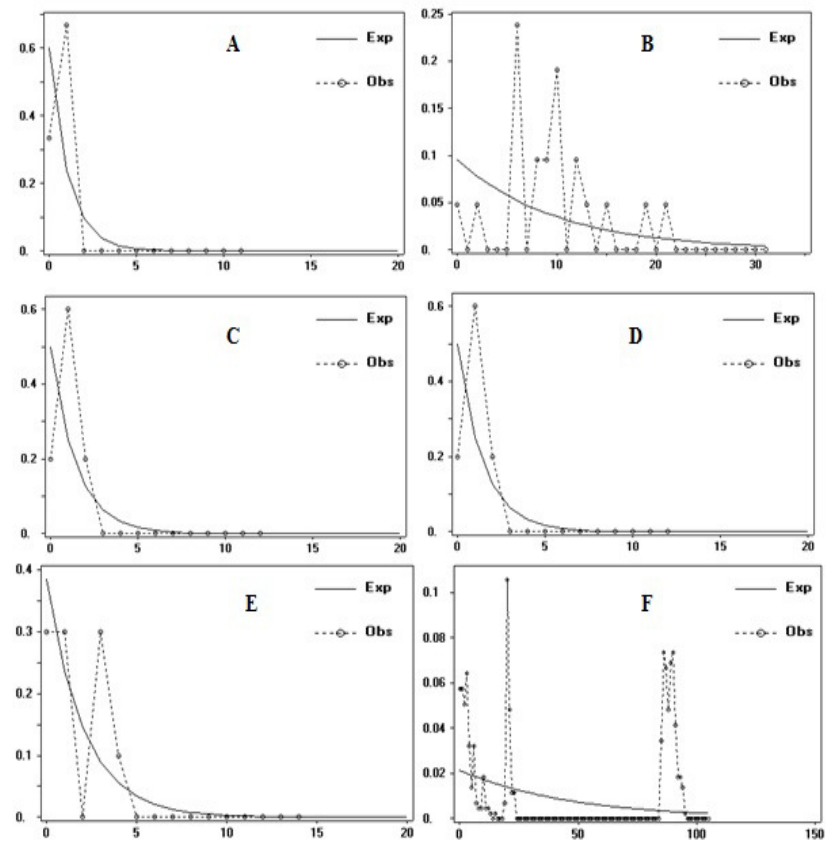

Fig. 4. Mismatch distribution of COI haplotypes in E. tetradactylum populations. (A-Arabian Sea; B-Bay of Bengal; C-North West Australia; D-North Australia; E-North East Australia; F-Overall population)

Table 3.K2P genetic distance between populations (below diagonal), within populations (bold) and pairwise $\mathrm{F}_{\mathrm{s}} \mathrm{values}$ (above diagonal) for $\mathrm{COI}$ sequences in $E$. tetradactylum

\begin{tabular}{lllllll}
\hline Population & Arabian Sea & BayofBengal & South China sea & North East Australia & North West Australia & North Australia \\
\hline Arabian Sea & $\mathbf{0 . 0 0 1}$ & 0.2728 & $1.0000^{*}$ & $0.9945^{*}$ & $0.9964^{*}$ & $0.9962^{*}$ \\
Bay of Bengal & 0.014 & $\mathbf{0 . 0 1 6}$ & $0.9811^{*}$ & $0.9809^{*}$ & $0.9844^{*}$ & $0.9853^{*}$ \\
South China Sea & 0.161 & 0.167 & $\mathbf{0 . 0 0 0}$ & $0.9805^{*}$ & $0.9851^{*}$ & $0.9846^{*}$ \\
North East Australia & 0.161 & 0.167 & 0.035 & $\mathbf{0 . 0 0 2}$ & $0.8538^{*}$ & 0.4896 \\
North West Australia & 0.163 & 0.170 & 0.034 & 0.006 & $\mathbf{0 . 0 0 2}$ & 0.006 \\
North Australia & 0.161 & 0.167 & 0.035 & 0.003 & $\mathbf{0 . 0 0 3}$ \\
\hline Overall mean & 0.085 & & & & & \\
\hline
\end{tabular}

Table 4. Analysis of molecular variance (AMOVA) for the COI sequences in E. tetradactylum.

\begin{tabular}{|c|c|c|c|c|}
\hline Source of variation & $D f$ & Sum of squares & Variance components & Percentage of variation \\
\hline Among groups* & 1 & 1167.458 & 39.334 & 92.10 \\
\hline Among populations & 4 & 216.670 & 3.029 & 7.09 \\
\hline Within populations* & 101 & 34.934 & 0.3458 & 0.81 \\
\hline${ }^{*} P$ value & $0.0791 \pm 0.0089$ & & & \\
\hline
\end{tabular}

Table 5. Statistical tests for neutrality for $E$. tetradactylum based on mitochondrial $C O I$ sequence data

\begin{tabular}{lcccc}
\hline & \multicolumn{3}{c}{ Tajima's $D$} & $F$ \\
\hline & $D$ & $P$ value $F$ & $P$ value \\
\hline Arabian Sea & 0.0000 & 1.0000 & 0.0000 & -0.6642 \\
Bay of Bengal & 0.5731 & 0.9990 & -2.9605 & -3.9224 \\
South China sea & 0.0000 & 1.0000 & -3.7255 & 0.8040 \\
North East Australia & 1.4302 & 0.9910 & 0.0000 & 0.0910 \\
North West Australia & 0.4289 & 0.9540 & 0.0270 \\
North Australia & 0.4854 & 0.9420 & 0.0130 \\
Mean \pm SD & $0.4863 \pm 0.4786$ & $0.9810 \pm 0.0237$ & $0.0000 \pm 0.0000$ \\
\hline
\end{tabular}


population expansion in most of the $E$. tetradactylum populations. Moreover, the haplotype network also confirmed recent population expansion following a population bottleneck in most of the studied populations. However, positive selection could also result in an excess of low-frequency haplotypes in many populations, making it difficult to unambiguously discern between evidence for natural selection and demographic population expansion. To distinguish these scenarios, further analysis of several unlinked loci in the genome is necessary, because the selection affects only specific loci (Grant et al., 2006). According to the $F_{\mathrm{ST}}$ analysis, a significant genetic differentiation was observed between the Arabian Sea and South China Sea populations. Many factors, including historical factors, anthropogenic activity, habitation, and a low rate of mitochondrial evolution, can influence genetic population structure (Avise, 2004; Grant et al., 2006). However, the $F_{\mathrm{ST}}$ value between Arabian Sea and Bay of Bengal as well as the three Australian populations were low, which suggest genetic similarities between the sampled regions. In general genetic homogeneity in marine fishes can be attributed to high dispersal potential during the planktonic egg and larval stages coupled with an absence of physical barriers between ocean basins and adjacent continental margins. Previous studies have revealed that the ocean currents in the China Sea facilitate the dispersal of marine larvae among distant populations (Han et al., 2008; Shui et al., 2009; Xiao et al., 2009). Data analysis from the COI gene sequences revealed genetic heterogeneity in E. tetradactylum populations in 51, 57,61 and 71 FAO fishing areas. The population structure shows that subdivisions exist between the studied areas. The sample size and geographical diversity of the populations were limited in this study. The use of multiple genetic marker systems can increase the resolving power of genetic studies (Gruenthal et al., 2007). Furthermore, molecular studies comprise a higher number of molecular markers including nuclear markers which are still required to precisely evaluate the genetic structure of $E$. tetradactylum throughout the globe.

\section{Acknowledgements}

We thank the Department of Biotechnology, Government of India, New Delhi, for financial assistance in the form of RGYI (BT/PR6419/GBD/27/434/2012). We also thank the CAS Director, in Marine Biology and The Authorities of Annamalai University for their facilitation and encouragement.

\section{References}

Chang NN, Shiao JC, GongJC (2012). Diversity of demersal fish in the East China Sea: implication of eutrophication and fishery. Continental Shelf Research 47: 42-54.

Excoffier L, Laval G, Schneider S (2008). Arlequin ver 3.1: An Integrated Software Package for Population Genetics Data Analysis. Bern, Switzerland: Computational and Molecular Population Genetics Lab, Institute of Zoology, University of Bern.

Fu YX (1997). Statistical tests of neutrality of mutations against population growth, hitchhiking and background selection. Genetics $147(2): 915-925$.
Grant WS, Spies IB, Canino MF (2006). Biogeographic evidence for selection on mitochondrial DNA in North Pacific Walleye Pollock Theragra chalcogramma. Journal of Heredity 97(6):571-580.

Grant W, Bowen B (1998). Shallow population histories in deep evolutionary lineages of marine fishes: Insights from sardines and anchovies and lessons for conservation. Journal of Heredity 89:415426.

Gruenthal KM, Acheson LK, Burton RS (2007). Genetic structure of natural populations of California red abalone (Haliotis rufescens) using multiple genetic markers. Marine Biology 152:1237-1248.

Habib KA, Jeong D, Myoung JG, Kim MS, Jang YS, Shim JS, Lee YH (2011). Population genetic structure and demographic history of the fat greenling Hexagrammos otakii. Genes and Genomics 33:413-423.

Han ZQ, Gao TX, Yanagimoto T, Sankurai Y (2008). Genetic population structure of Nibea albiflora in Yellow Sea and East China Sea. Fisheries Sciences 74:544-552.

Harpending HC, Sherry ST, Rogers AR, Stoneking M (1993). The genetic structure of ancient human populations. Current Anthropology 34:483-496.

Horne JB, Momigliano P, Welch DJ, Newman SJ, Herwerden L (2011). Limited ecological population connectivity suggests low demands on self-recruitment in a tropical inshore marine fish (Eleutheronema tetradactylum: Polynemidae). Molecular Ecology 20:2291-2306.

Jones GP, Almany GR, Russ GR, Sale PF, Steneck RS, Van Oppen MJH, Willis BL (2009). Larval retention and connectivity among populations of corals and reef fishes: history advances and challenges. Coral Reefs 28(2):307-325.

Liu F, Xia JH, Bai ZY, Fu JJ, Li JL, Yue GH (2009). High genetic diversity and substantial population differentiation in grass carp (Ctenopharyngodon idella) revealed by microsatellite analysis. Aquaculture 297(1):51-56.

Lynch M, Crease TJ (1990). The analysis of population survey data on DNA sequence variation. Molecular Biology and Evolution 7(4):377-394.

Ma CY, Cheng QQ, Zhang QY, Zhuang P, Zhao YL (2010). Genetic variation of Coilia ectenes (Clupeiformes: Engraulidae) revealed by the complete cytochrome b sequences of mitochondrial DNA. Journal of Experimental Marine Biology and Ecology 385:14-19.

Machado-Schiaffino G, Garcia-Vazquez E (2011). Population structure of long tailed hake Macruronus magellanicus in the Pacific and Atlantic oceans: implications for fisheries management. Fisheries Research 111:164-169.

Moore BR, Stapley J, Allsop Q, Newman SJ, Ballagh A, Welch DJ, Lester RJG (2011). Stock structure of blue threadfin Eleutheronema tetradactylum across northern Australia, as indicated by parasites. Journal of Fish Biology 78:923-936.

Motomura H (2004). Threadfins of the world. An annotated and illustrated catalogue of polynemid species known to date. Family Polynemidae. FAO Species Catalogue for Fishery Purpose No3, FAO, Rome pp117. 
422

Motomura H, Iwatsuki Y, Kimura S, Yoshino T (2002). Revision of the Indo-West Pacific polynemid fish genus Eleutheronema (Teleostei: Perciformes). Ichthyological Research 49(1):47-61.

Nei M (1987). Molecular Evolutionary Genetics. Columbia University Press, New York, USA pp 10-88.

Newman SJ, Pember MB, Rome BM, Mitsopoulos GEA, Skepper CL, Allsop Q, Welch DJ (2011). Stock structure of blue threadfin Eleutheronema tetradactylum across Northern Australia as inferred from stable isotopes in sagittal otolith carbonate. Fisheries Management and Ecology 18(3):246257.

Peng S, Shi ZH, Hou J, Wang W, Zhao F, Zhang H (2009). Genetic diversity of silver pomfret (Pampus argenteus) populations from the China Sea based on mitochondrial DNA control region sequences. Biochemical Systematics and Ecology 37(5):626-632.

Rogers AR (1995). Genetic evidence for a Pleistocene population explosion. Evolution 49:608-615.

Röhl A, Mihn D (2003). Network: A program package for calculating phylogenetic networks. Mathematisches Seminar, University of Hamburg, Hamburg.

Rozas J, Sánchez-DelBarrio JC, Messeguer X, Rozas R (2003). DnaSP, DNA polymorphism analyses by the coalescent and other methods. Bioinformatics 19(18):2496-2497.

Saitou N, Nei M (1987). The neighbor-joining method: a new method for reconstructing phylogenetic trees. Molecular Biology and Evolution 4(4):406-425.

Sambrook, J, Fritsch EF, Maniatis T (1989). Molecular Cloning: A Laboratory Manual, second ed. Cold Spring Harbor Laboratory Press, New York, Cold Springs Harbor.

Shui BN, Han ZQ, Gao TX, Miao ZQ, Yanagimoto T (2009). Mitochondrial DNA variation in the East China Sea and Yellow Sea populations of Japanese Spanish mackerel Scomberomorus niphonius. Fisheries Science 75(3):593-600

Spies IB, Gaichas S, Stevenson DE, Orr JW, Canino MF (2006). DNA-based identification of Alaska skates (Amblyraja, Bathyraja and Raja: Rajidae) using cytochrome c oxidase subunit I (COI) variation. Journal of Fish Biology 69(sb):283-292.
Sun X, Xu D, Lou B, Zhang T, Xin J, Guo Y, Ma S (2013). Genetic diversity and population structure of Eleutheronema rhadinum in the East and South China Seas revealed in mitochondrial COI sequences. Chinese Journal of Oceanology and Limnology 31:1276-1283.

Tajima F (1989). Statistical method for testing the neutral mutation hypothesis by DNA polymorphism. Genetics 123(3):585-595.

Tamura K, Dudley J, Nei M, Kumar S (2007). MEGA4: molecular evolutionary genetics analysis (MEGA) software version 4.0. Molecular Biology and Evolution, 24(8):1596-1599.

Ward RD, Zemlak TS, Innes BH, Last PR, Hebert PD (2005). DNA barcoding Australia's fish species. Philosophical Transactions of the Royal Society B: Biological Sciences 360(1462):1847-1857.

Welch DJ, Gribble NA, Garrett RN (2002). Assessment of the threadfin salmon fishery in Queensland 2002. Queensland Department of Primary Industries, Report No. QI02115, Northern Fisheries Centre, Cairns pp 20.

Xiao YS, Zhang Y, Gao TX, Yanagimo T, Yabe M, Sakurai Y (2009). Genetic diversity in the mtDNA control region and population structure in the small yellow croaker Larimichthys polyactis. Environmental Biology of Fishes 85(4):303-314.

Xu D, Lou B, Shi H, Geng Z, Li S, Zhang YR (2012). Genetic diversity and population structure of Nibea albiflora in the China Sea revealed by mitochondrial COI sequences. Biochemical Systematics and Ecology 45:158-165.

Yamada U, Shirai S, Irie T, Tokimura M, Deng S, Zheng Y, Li C, Kim YU, Kim YS (1995). Names and Illustrations of Fishes from the East China Sea and the Yellow Sea. Overseas Fishery Cooperation Foundation, Tokyo, Japan p 288.

Yue GH, Zhu ZY, Lo LC, Wang CM, Lin G, Feng F, Orban L (2009). Genetic variation and population structure of Asian seabass (Lates calcarifer) in the Asia-Pacific region. Aquaculture 293(1):22-28.

Zischke MT, Cribb TH, Welch DJ, Sawynok W, Lester RJG (2009). Stock structure of blue threadfin Eleutheronema tetradactylum on the Queensland east coast, as determined by parasites and conventional tagging. Journal of Fish Biology 75(1):156-171. 